\title{
Do the determinants of self-rated health vary among older people with disability, chronic diseases or both conditions in urban Colombia?
}

\author{
¿Varían los determinantes de la salud autoevaluada \\ entre las personas ancianas con discapacidad, \\ enfermedades crónicas o ambas condiciones \\ en áreas urbanas de Colombia?
}

\begin{abstract}
Os determinantes da autopercepção da saúde variam entre idosos com deficiência, com doenças crônicas não transmissíveis ou com ambas condições

nas áreas urbanas da Colômbia?
\end{abstract}

Monica Pinilla-Roncancio 1 Catalina González-Uribe 1 Diego I. Lucumi 1

doi: 10.1590/0102-311X00041719

\begin{abstract}
Our study aimed to identify the main determinants of self-rated health for individuals aged 60 years or older in Bogotá, Colombia, and if those determinants vary between groups. Data was obtained from the Demographic Health Survey 2011 for Bogotá. Logistic regression models were estimated to identify the determinants of excellent/good self-rated health among people aged 60 years or older living in Bogotá. Moreover, a subgroup analysis was conducted seeking to identify if the determinants changed between groups (men, women, persons with disability, with chronic disease(s), and persons with both disability and chronic disease(s)). The likelihood of reporting an excellent/good self-rated health health decreases when the individual has a disability, a chronic disease or reports that their household income is not enough to cover the basic needs. On the other hand, the odds of reporting excellent/ good self-rated health increase when the individual is more educated and reports to receive family support. The subgroup analysis showed that although some determinants are only associated with one group (age with chronic diseases), in general, three main determinants stood out: years of education, socioeconomic status variables and receiving family support. The determinants of self-rated health for older adults in Bogota differ according to the disability and the chronic disease status. Thus, public policies aiming to improve the levels of health and quality must consider the impacts of those characteristics on individuals' perceptions of their own health.
\end{abstract}

Disable Persons; Aged; Chronic Disease; Urban Area
Correspondence

M. Pinilla-Roncancio

Universidad de los Andes.

Calle 1467 B 50, Bogotá 110121, Colombia.

mv.pinilla@uniandes.edu.co

1 Universidade de los Andes, Bogotá, Colombia. 


\section{Introduction}

Globally, the older population is expected to double by 2050 1. All regions worldwide are experiencing population aging, and the older individuals age group is growing relatively faster than younger age groups ${ }^{1}$. Latin America is expected to experience the fastest growth among those aged 60 years or older in the following decade, followed by Asia, Africa, Oceania, North America and Europe 1,2. Latin America is simultaneously experiencing fast rates of urbanization when compared with other regions, being considered the most unequal region of the world 1,2. Latin America adults are growing old in relatively scarce settings with poor living conditions and large socioeconomic inequalities and are also a less healthy group, since they face a higher number of chronic diseases and disability 3. Few studies investigating older adults and their health and disability challenges are found for this region 4,5,6,7,8. Population aging represents challenges across all sectors along with significant social changes, such as internal and external migration and post-conflict settings as in the case of Colombia. Advancing health status and well-being into old age requires evidence for local governments to address structural policy changes.

Colombia has experienced changes in its population, including a reduction in the fertility rate and an increase in life expectancy ${ }^{9}$. Fertility rate declined from 2.02 per woman in 2000 to 1.91 in 20159. In addition, it was estimated that in 2017 more than $11 \%$ of the population in the country were older than 60 , and $17 \%$ were younger than 10 years 10 . Given these characteristics, Colombia is classified in the stage of moderately advanced aging, as well as other Latin America countries such as Brazil, Costa Rica and El Salvador ${ }^{11}$. The continuing growth in the aging population in the country, and particularly in urban settings, has become a public health challenge, together with sharp socioeconomic inequalities and the aftermath of decades of civil conflict.

Considering the increased percentage of people older than 60, this group has become the most vulnerable population to face the negative consequences of non-communicable disease(s), including chronic health problems 11. In the urban context, it has become a key feature. Chronic disease(s) such as cardiovascular disease and diabetes are among the leading causes of death, especially in most urbanized areas of the country 12, including Bogotá, which is the main urban area of Colombia. Regarding disabilities, individuals older than 45 years are more likely to live with impairments or severe difficulties for different activities 13 . In the specific case of Colombia, the prevalence of disability is greater in urban settings and in people with lower socioeconomic status 14 .

Despite the aforementioned evidence on the substantial changes and impacts of the aging process in Colombia's urban areas, studies on the assessment of the overall health status of older adults in Bogotá are scarce 15,16,17. This is problematic, since the well-being of this population is highly influenced by the physical and mental functioning needed for an active and successful engagement in social, economic, and political activities 18. The gathering of evidence in this field for the city should take advantage of existing studies using reliable measurements for the assessment of overall health status at the population level.

Self-rated health is a widely-used reliable measure of health in research and clinical practice worldwide, which is based on the reported assessment of one's own health that can differ according to individual and contextual characteristics 15,19. Despite the lack of consensus on a definition of selfrated health, studies across different cultural contexts show its association with disability 20 ; morbidity 21,22,23; mortality 24 and use of health care services 25 .

How people think and respond to the question "How do you rate your current health?" has been shown to vary across cultures and to change across the lifespan 26 . Individuals assess and rate their health status by considering a group of factors, including physical functioning, emotional well-being, morbidity and health limitations, as well as the physical and social environment 19,24. Studies of older adults have shown that aspects related to their gender, socioeconomic status, and perceived social support are associated with differences in self-rated health $27,28,29$.

Poor self-rated health can signal adverse psychosocial and physical states that trigger morbidity and mortality, since aging is associated with a higher risk of non-communicable disease(s) and disability, as well as social vulnerability, including social isolation and negative life events 15 . Evidence is limited for Latin America, particularly regarding self-rated health among older men and women with a disability, a chronic disease, or both conditions 30 . Understanding self-rated health among urban 
older populations requires evidence for policy changes considering demographic and socio-political changes, and weak social assistance programs. Describing gender patterns in self-rated health associations with disability and morbidity of chronic disease(s) contributes to the literature.

Our paper seeks, firstly, to identify how much the probability of reporting an excellent/good health status changes when individuals aged 60 years or older report living with a disability or a chronic condition. Based on previous studies, we hypothesized that people with disability or a chronic condition in Bogotá are likely to report worse health status than those with no reported chronic disease and/or disability status. Secondly, to analyze how different social characteristics are associated with the probability of having excellent/good self-rated health for older adults living with disability or chronic disease(s), and those living with both conditions. Our study aims to narrow the gap in the literature about self-rated health in middle-income countries among older adults. The context of Bogotá as the main urban area of Colombia is important because the city's age pyramid, history of fertility, conflict and migration provides relevant information to the region and in similar countries in the world.

\section{Materials and methods}

\section{Data}

Our study uses secondary data from the Demographic Household Survey from Bogotá (DHS-B), 2011. Its main purpose was to collect demographic and health information from rural and urban areas of Bogotá, including its 20 localities. The DHS-B uses five questionnaires, designed for households, children, women, men, and individuals aged 60 years or older 31 .

DHS-B uses a probabilistic conglomerate, multi-stage sampling frame, with two phases of data selection (blocks and segments). It is representative for Bogotá and for population aged 60 years or older living in the city ${ }^{31}$. It collects information on specific topics for men and women in different age groups. DHS-B is the only survey including questions related to self-rated health and socioeconomic variables representative for people 60 years or older. The final sample of the survey was 10,411 households, with a $74.4 \%$ response rate at the household level and a sample of 3,360 individuals aged 60 years or older, with an $89 \%$ response rate 31 .

\section{Methods}

\section{- Dependent variable}

The outcome variable for our study is self-rated health. This variable was measured in the older adult's module, by asking individuals to rank their health status according to five categories: excellent, very good, good, regular, and bad 32,33. Based on this information, we created a dichotomous variable that classified individuals between having good (excellent, very good, and good) health status or bad health status (regular and bad).

\section{- Independent variables}

\section{(a) Disability status}

DHS-B 2011 included a question aimed to collect information related to difficulties to conduct a range of activities in the last 30 days. Activities included difficulties in concentrating, learning, standing for more than 30 minutes, walking, activities of daily living (e.g., bathing and dressing), relationships with others, and participation 33 . The answers were used to identify individuals with different types of difficulty. Each question included a range of severities, therefore, the individual needed to self-report the difficulty with the activities and its severity. The severity scale ranges from "no difficulty" to "extreme difficulty" (or impossibility to perform it). Individuals that reported having extreme, severe or moderate difficulties in one or more categories were classified as individuals with disability 34 . 


\section{(b) Chronic disease(s)}

DHS-B 2011 included self-reported questions related to the previous existence of a diagnosis of different chronic diseases (diabetes, hypertension, arthritis, chronic obstructive pulmonary disease - COPD, or cancer). Individuals who answered "yes" to at least one disease were classified as "people living with chronic disease(s)".

\section{(c) Other independent variables}

We controlled for several individual and household characteristics. Firstly, we included variables related to age (years), gender (male/female), years of schooling and employment status (working/not working), as these variables have been identified as common factors affecting the individual's levels of health, and, therefore, self-rated health 24,27,28,35,36. Health insurance was also included as a determinant of self-rated health status due to its importance in providing access to health care services in Colombia, expecting that the better a person's health care insurance, the more positively his/her level of health care will be affected 37 . Health insurance is categorized by Colombian standards into four categories: "contributory", "subsidized", "special", and "none" 38. The contributory regime relies on the compulsory affiliation of paid workers and population groups with payment capacity. The subsidized regimen covers the population without capacity to pay compulsory premiums; beneficiaries are selected through the System of Identification of Social Program Beneficiaries (SISBEN) socioeconomic survey. The special regimen targets individuals employed through the Colombian Petroleum Company, teachers in public universities, the National Congress, and military and police forces 38 .

We included three variables capturing socioeconomic status. Living in the lowest quintile of the household wealth index 39 ; a three-level socioeconomic stratum variable, which used information from the national categorization of socioeconomic stratum in Colombia, and aimed to classified households according to the characteristics of their neighborhood ("low", "middle", and "high stratum") 40; and a variable capturing the perception of households regarding the sufficiency of the household income to cover their needs ("not enough", and "enough/more than enough"). Moreover, we included a variable capturing psychological support provided by other family members. This variable was the highest quintile of an index computed using multiple correspondence analysis, which combined the results of five questions related to family support. Finally, to capture the association between the social environments in which the person lives and the individual's health status, variables related to the locality where the person lived was added to the model.

\section{Methods of analysis}

The first phase of the analysis describes the characteristics of individuals aged 60 years or more, living with a disability or living with a chronic disease. According to the type of variable, the t-test or the Pearson's chi-square test were used to analyze differences between groups. In the second phase, a logistic regression model was used to identify how much the probability of reporting an excellent/ good health status changed according to individual and socioeconomic characteristics. Odds ratios (OR) were estimated to analyze the association between independent, dependent and cofounder variables 41 .

For the multivariate analysis, we tested different models separately for three different groups of interest: people with disability, people with chronic disease(s), and people living with both disability and chronic disease(s). First, the effects of the individual characteristics ("age", "sex", "years of education" and "employment status"). Second, we adjusted for health insurance status. Then, we further adjusted for the socioeconomic status characteristics of the household ("wealth index", "socioeconomic stratum", "perceived poverty" and "locality"). Finally, covariates that were statistically significantly associated with the dependent and the main independent variables (disability and chronic disease) were included simultaneously. All the models were estimated using Stata 15 (https:// www.stata.com/).

We first tested the need of computing a hierarchical model with random coefficient effects versus computing an empty logistic model due to the importance of contextual variables in the levels of self- 
rated health 42,43 . In all cases, the null hypothesis was rejected; therefore, no significant variation of self-reported health at the locality level was observed.

\section{- Robustness test}

To test the robustness of the results, we estimated a model using a self-rated health variable with three categories: "good health" (excellent and very good and good), "regular health", and "bad health" status. As in the main model, the results were estimated by sex, living with a disability, with a chronic disease(s) and with both a disability and a chronic condition.

\section{Results}

Table 1 showed that, among people 60 years and older in Bogotá, 64.7\% reported diagnosis of chronic disease(s), $40.8 \%$ reported living with a disability, and $31.1 \%$ reported living with both chronic disease(s) and disability. Most of the participants were female (61.7\%), without enough income to cover their needs (57.8\%), lived in a neighborhood with middle socioeconomic stratum (71.9\%), and had contributory health-care insurance (72.3\%). The prevalence of excellent/good health status was lower among people with both a chronic disease and a disability (36\%) and higher for people that reported only a disability (42.6\%), only chronic disease (53.5\%), and no reported disability or chronic disease (88.9\%).

\section{General model}

Table 2 shows the results of the general model, which analyzes the association between reporting excellent/good self-reported health and the list of variables presented in the previous section. The results showed no significant differences in the likelihood of reporting an excellent/good health status between male and female. Moreover, the increase of one year of education increased by $5 \%$ the odds of reporting excellent/good health status ( $\mathrm{p}$-value $<0.05$ ). A person with disability is $74 \%$ less likely to report an excellent/good health status, when compared with a person without disability (p-value < 0.05). Regarding individuals with chronic conditions, the likelihood reduce by $70 \%$, when compared with people without chronic conditions ( $\mathrm{p}$-value $<0.05$ ). Characteristics such as age, marital status, and being employed were not associated with reporting an excellent/good health status. Having health insurance provision different from a contributory regime reduced the odds of reporting an excellent/good health status; however, neither of these variables was significant ( $\mathrm{p}$-value $>0.05$ ).

The analysis of variables related to socioeconomic status revealed that the odds of reporting an excellent/good health status was $24 \%$ lower among people in the lowest quintile of the wealth index, when compared with people not living in this quintile ( $\mathrm{p}$-value $<0.05$ ). Moreover, the probability of reporting an excellent/good health status was 51\% lower for those who stated that their levels of income were not enough to cover their expenses, when compared with people who reported an income sufficient or more to cover the family expenses ( $\mathrm{p}$-value $<0.05$ ), and people aged 60 or older living in the highest levels of socioeconomic stratum had higher chances of reporting an excellent/good health status (65\%), when compared with people living in the lowest level (p-value $<0.1$ ). Finally, the variable measuring family support increased the odds of reporting an excellent/good health status: indeed, an individual reporting high levels of family support had $46 \%$ more chances of having excellent/good health status when compared with people with lower levels of family support (p-value $<0.05)$.

\section{Self-rated health by gender}

Table 3 showed that, when the analysis was conducted for men and women separately, the results evidenced that the odds of reporting an excellent/good health status increased by $7 \%$ for women by each year more of education ( $\mathrm{p}$-value $<0.05$ ). If a woman had a disability, the likelihood of having an excellent/good self-rated health was $75 \%$ lower when compared with a woman without a disability. A 
Descriptive statistics of characteristics of individuals aged 60 years or older living in Bogotá, Colombia (Demographic Household Survey from Bogotá DHS-B, 2011).

\begin{tabular}{|c|c|c|c|c|c|}
\hline & $\begin{array}{c}\text { Total } \\
(\mathrm{N}=3,360)\end{array}$ & $\begin{array}{l}\text { People with } \\
\text { disabilities } \\
(n=1,508)\end{array}$ & $\begin{array}{c}\text { People with chronic } \\
\text { diseases } \\
(n=2,204)\end{array}$ & $\begin{array}{l}\text { People with disability } \\
\text { and chronic diseases } \\
\qquad(n=1,170)\end{array}$ & $\begin{array}{l}\text { People without disability } \\
\text { or chronic diseases } \\
\qquad(n=818)\end{array}$ \\
\hline People with disability (\%) & $40.8(0.014)$ & & & & \\
\hline People with chronic diseases (\%) & $64.7(0.012)$ & & & & \\
\hline $\begin{array}{l}\text { People with disabilities and } \\
\text { chronic diseases (\%) }\end{array}$ & $31.1(0.012)$ & & & & \\
\hline $\begin{array}{l}\text { People without chronic diseases } \\
\text { or disabilities (\%) }\end{array}$ & $25.6(0.012)$ & & & & \\
\hline Excellent/Good health status (\%) & $63.5(0.129)$ & $42.6(0.203)$ & $53.5(0.017)$ & $36.0(0.023)$ & $88.9(0.013)$ \\
\hline Women (\%) & $61.7(0.209)$ & $69.3(0.016)$ & $65.9(0.013)$ & $72.3(0.018)$ & $51.8(0.024)$ \\
\hline Average age in years & $69.9(0.013)$ & $72,7(0.348)$ & $71.2(0.247)$ & $73.4(0.357)$ & $66.6(0.322)$ \\
\hline $\begin{array}{l}\text { Average number of years of } \\
\text { schooling }\end{array}$ & $7.7(0.191)$ & $6,3(0.243)$ & $7.2(0.218)$ & $6.0(0.247)$ & $9.1(0.316)$ \\
\hline People working (\%) & $20.6(0.009)$ & $12.7(0.012)$ & $15.7(0.011)$ & $9.8(0.097)$ & $32.1(0.321)$ \\
\hline \multicolumn{6}{|l|}{ Subjective poverty (\%) } \\
\hline Not enough to cover & $57.8(0.015)$ & $62.6(0.019)$ & $60.3(0.017)$ & $62.8(0.022)$ & $49.8(0.026)$ \\
\hline Just cover needs & $36.8(0.014)$ & $34.6(0.019)$ & $35.1(0.016)$ & $34.4(0.022)$ & $42.0(0.026)$ \\
\hline More than enough & $5.4(0.007)$ & $2.8(0.005)$ & $4.7(0.007)$ & $2.75(0.006)$ & $8.2(0.016)$ \\
\hline \multicolumn{6}{|l|}{ Strata level (\%) } \\
\hline Lowest & $6.1(0.006)$ & $6.3(0.008)$ & $6.0(0.007)$ & $5.9(0.008)$ & $6.0(0.010)$ \\
\hline Middle & $71.9(0.019)$ & $76.5(0.021)$ & $73.1(0.02)$ & $77.0(0.022)$ & $67.7(0.030)$ \\
\hline Highest & $22.0(0.018)$ & $17.2(0.02)$ & $20.9(0.019)$ & $17.0(0.021)$ & $26.3(0.030)$ \\
\hline \multicolumn{6}{|l|}{ Health care insurance (\%) } \\
\hline Contributory & $72.3(0.012)$ & $70.3(0.016)$ & $73.5(0.014)$ & $70.6(0.019)$ & $74.1(0.021)$ \\
\hline Subsidized & $17.2(0.009)$ & $19.6(0.013)$ & $16.3(0.009)$ & $19.4(0.014)$ & $18.1(0.018)$ \\
\hline Special regime & $6.1(0.008)$ & $6.5(0.010)$ & $7.0(0.009)$ & $7.2(0.011)$ & $4.5(0.010)$ \\
\hline No health insurance & $3.4(0.005)$ & $3.5(0.006)$ & $3.2(0.006)$ & $2.8(0.007)$ & $3.3(0.007)$ \\
\hline Lowest quintile wealth index (\%) & $13.7(0.137)$ & $15.5(0.014)$ & $14.1(0.01)$ & $15.1(0.015)$ & $11.4(0.013)$ \\
\hline
\end{tabular}

Note: standard errors in parentheses.

similar result was found among women with chronic diseases, in which the odds or reporting excellent/good self-rated health decreased by $70 \%$ when compared with women without chronic disease(s). Additionally, women who reported living in a household whose income was not enough to cover their needs had 53\% less chances to report excellent/good self-rated health when compared with women who reported living in a household whose income was enough (or more than enough) to cover their needs ( $p$-value $<0.01$ ). Women in the highest socioeconomic stratum had $125 \%$ more chances of reporting an excellent/good health status compared to women in the lowest stratum level (p-value < 0.01). Finally, women who reported receiving family support had $43 \%$ more chances of reporting an excellent/good health status compared to women who did not have family support (p-value $<0.01$ ).

Regarding men, the odds of reporting an excellent/good health status increased $4 \%$ by each year more of education. Moreover, the odds reduced by $74 \%$ and $71 \%$ when men were living with a disability or a chronic disease(s) compared to men without a disability or a chronic disease(s), respectively ( $\mathrm{p}$-value $<0.01$ ). Men in the lowest quintile of the wealth index had 42\% less chances of reporting an excellent/good self-rated health compared to men in higher levels of the wealth index (p-value $<0.01$ ). Finally, men who reported receiving family support had 59\% more chances of having an excellent/ good health status compared to men who did not receive family support ( $\mathrm{p}$-value $<0.01$ ). 


\section{Table 2}

Odds ratios (OR) of determinants of excellent/good self-rated health for individuals aged 60 years or older in Bogotá, Colombia (Demographic Household Survey from Bogotá - DHS-B, 2011).

\begin{tabular}{lc}
\hline Self-rated health: excellent/good & OR \\
\hline Age (in years) & $1.00(0.01)$ \\
Female & $1.00(0.01)$ \\
Married: yes & $0.95(0.09)$ \\
Years of schooling & $1.05 *(0.01)$ \\
Disability: yes & $0.26 *(0.04)$ \\
Chronic disease: yes & $0.30 *(0.04)$ \\
Working: yes & $1.07(0.12)$ \\
Health insurance: subsidized regime & $0.90(0.10)$ \\
Health insurance: special regime & $0.85(0.16)$ \\
Health insurance: none & $0.82(0.18)$ \\
Lowest quintile wealth index & $0.76 * *(0.09)$ \\
Not enough income to cover household needs & $0.49 *(0.05)$ \\
Middle socioeconomic strata & $1.01(0.20)$ \\
Higher socioeconomic strata & $1.64 * *(0.44)$ \\
Always receiving support from their families: yes & $1.48 *(0.13)$ \\
\hline
\end{tabular}

Note: total of observations: 3,204. Standard errors in parenthesis.

$*$ p-value $<0.01$.

$* *$ p-value $<0.05$;

$\star * *$ p-value $<0.10$.

\section{Table 3}

Odds ratios (OR) of determinants of excellent/good self-rated health for men and women aged 60 years or older living in Bogotá, Colombia (Demographic Household Survey from Bogotá - DHS-B, 2011).

\begin{tabular}{|c|c|c|}
\hline Self-rated health: excellent/good & $\begin{array}{c}\text { Female } \\
\text { OR }\end{array}$ & $\begin{array}{l}\text { Male } \\
\text { OR }\end{array}$ \\
\hline Age (in years) & $1.01(0.01)$ & $0.98(0.01)$ \\
\hline Years of schooling & $1.07 *(0.02)$ & $1.04 * *(0.02)$ \\
\hline Married: yes & $0.91(0.11)$ & $1.06(0.17)$ \\
\hline Disability: yes & $0.25 *(0.06)$ & $0.26 *(0.06)$ \\
\hline Chronic disease: yes & $0.31 *(0.06)$ & $0.29 *(0.06)$ \\
\hline Working: yes & $1.04(0.17)$ & $1.02(0.16)$ \\
\hline Health insurance: subsidized regime & $0.91(0.13)$ & $0.91(0.18)$ \\
\hline Health insurance: special regime & $0.71(0.18)$ & $1.09(0.31)$ \\
\hline Health insurance: none & $0.88(0.25)$ & $0.73(0.26)$ \\
\hline Lowest quintile wealth index & $0.96(0.14)$ & $0.58 *(0.11)$ \\
\hline Not enough income to cover household needs & $0.47 *(0.06)$ & $0.50 *(0.08)$ \\
\hline Middle socioeconomic strata & $1.18(0.31)$ & $0.85(0.27)$ \\
\hline Higher socioeconomic strata & $2.24 * *(0.77)$ & $0.95(0.43)$ \\
\hline Always receiving support from their families: yes & $1.44 *(0.16)$ & $1.59 *(0.23)$ \\
\hline
\end{tabular}

Note: total of observations: female $(n=1,911)$; male $(n=1,293)$. Robust standard errors in parentheses.

* $\mathrm{p}$-value $<0.01$;

** $p$-value $<0.05$. 


\section{Self-rated health among people with disability}

Table 4 shows the results for people with disability, chronic disease or both. Among people older than 60 with a disability, who reported living in the lowest quintile of the wealth index had 26\% less chances to report an excellent/good health status compared to people in other quintiles (p-values < 0.01). In addition, the odds of reporting an excellent/good health status decreased by $51 \%$ if the person reported that their income was not enough to cover their needs (p-values $<0.01$ ). Finally, receiving family support increases the odds of reporting excellent/good health in $49 \%$ compared to people with disability who did not receive any family support.

\section{Self-rated health among people with chronic disease(s)}

Table 4 (second column) showed that the increase in each year of age increase the odds of reporting excellent/good health status by $2 \%$ (p-value $<0.01$ ) for people aged 60 years or older who reported living with chronic disease(s). Moreover, having an insurance in the subsidized health regime reduced the odds of reporting an excellent/good health status by $22 \%$. Furthermore, people with chronic disease(s) who reported that their income was not enough to cover their needs had a reduction on their chances of having an excellent/good health status by $49 \%$. Regarding people with disabilities, individuals with chronic disease in the highest socioeconomic stratum and reporting to receive family support had an OR equal to 2.07 and 1.64 of reporting an excellent/good health status compared to people in lower socioeconomic stratum or without any family support ( $\mathrm{p}$-value $<0.01$ ).

\section{Table 4}

Odds ratios (OR) determinants of excellent/good self-rated health for persons with disabilities or chronic diseases (or both conditions) aged 60 years or older living in Bogotá, Colombia (Demographic Household Survey from Bogotá - DHS-B, 2011).

\begin{tabular}{|c|c|c|c|}
\hline \multirow[t]{2}{*}{ Self-rated health: excellent/good } & People with disabilities & $\begin{array}{c}\text { People with chronic } \\
\text { diseases }\end{array}$ & $\begin{array}{c}\text { People with disabilities } \\
\text { and chronic diseases }\end{array}$ \\
\hline & OR & OR & OR \\
\hline Age (in years) & $0.99(0.01)$ & $0.98 *(0.01)$ & $1.00(0.01)$ \\
\hline Female: yes & $0.95(0.13)$ & $0.90(0.10)$ & $1.16(0.20)$ \\
\hline Married: yes & $0.91(0.12)$ & $0.88(0.10)$ & $0.83(0.13)$ \\
\hline Years of schooling & $1.04 * *(0.02)$ & $1.07 *(0.01)$ & $1.04 * *(0.02)$ \\
\hline Working: yes & $1.31(0.22)$ & $1.17(0.15)$ & $1.22(0.26)$ \\
\hline Health insurance: subsidized regime & $0.78(0.12)$ & $0.76 * *(0.10)$ & $0.58 *(0.11)$ \\
\hline Health insurance: special regime & $0.69(0.17)$ & $0.76(0.15)$ & $0.69(0.19)$ \\
\hline Health insurance: none & $0.88(0.28)$ & $0.69(0.21)$ & $0.48(0.25)$ \\
\hline Lowest quintile wealth index & $0.74 * \star \star(0.12)$ & $0.90(0.12)$ & $0.91(0.18)$ \\
\hline Not enough income to cover household needs & $0.49 *(0.07)$ & $0.51 *(0.05)$ & $0.57 *(0.09)$ \\
\hline Middle socioeconomic strata & $0.97(0.29)$ & $1.38(0.34)$ & $1.63(0.65)$ \\
\hline Higher socioeconomic strata & $1.61(0.60)$ & $2.07 * *(0.65)$ & $2.81 * *(1.34)$ \\
\hline Always receiving support from their families: yes & $1.61 *(0.20)$ & $1.64 *(0.16)$ & $1.67 *(0.24)$ \\
\hline
\end{tabular}

Note: total of observations: people with disabilities $(n=1,427)$; people with chronic diseases $(n=2,113)$; people with disabilities and chronic diseases $(n=$ 1,112). Robust standard errors in parentheses.

* $\mathrm{p}$-value $<0.01$;

** p-value <0.05;

$\star \star *$ p-value $<0.10$. 


\section{Self-rated health among people with disability and a chronic disease(s)}

People living with a disability and chronic disease(s) who were insured in the subsidized regimen and reported that their income did not cover their needs had less chances of reporting an excellent health status ( $42 \%$ and $43 \%$, respectively), when compared with people in the contributory regime and people who reported their income was enough (or more than enough) to cover their needs (p-value $<0.01$ ). Finally, for this group, living in the highest socioeconomic stratum or receiving family support increased the odds of an excellent/good self-rated health compared to people in the lowest stratum or without family support ( $143 \%$ and $57 \%$, respectively) (p-value $<0.01$ ) (Table 4 , third column).

All models showed in this section included the 20 variables related to Locality; however, due to space limitations, these results were not included in the tables. The results in the main variables did not present any variation and in all cases, most Locality variables were not significant. The results of these variables are available upon request.

\section{- Robustness analysis}

When the models were estimated using a self-rated health three-level variable (excellent/good, regular and bad health status), we found similar results. On the one hand, odds of an excellent/good self-rated health increased compared to reporting bad self-rated health when the person had higher level of education, lived in the highest stratum level and received family support. On the third hand, the odds reduced when the individual was living with a disability or a chronic disease, lived in a household in the lowest level of the wealth index or in a household, whose income was not enough to cover the basic needs.

\section{Discussion}

Our paper analyzed the determinants of self-rated health for older adults living in Bogotá, Colombia. Different models were estimated to analyze if the factors affecting the levels of self-rated health were different between men, women, people with disability, people living with chronic disease(s), and those living with both disability and chronic disease(s). The results showed four main findings. First, lower odds of reporting excellent/good self-rated health are associated with living with a chronic disease and/or disability among men and women aged 60 years or older. Second, according to the sub-group (men, women, persons with disability and/or living with chronic conditions), different individual and socioeconomic factors were associated with excellent/good self-rated health for older adults. Third, although some factors differed between groups, three main factors were consistently associated with excellent/good self-rated health for older adults in Bogotá. These factors were "years of education", "socioeconomic status", and "family/social support". Finally, contrary to what was expected, self-rated health status was not significantly different between men and women.

As expected, living with disability and/or chronic disease(s) is negatively associated with reporting an excellent/good self-rated health status. This is a common finding in the literature 44 , since objective health measures such as chronic conditions are usually associated with reporting lower levels of self-rated health status. The results of the analysis also showed that people with disability have a lower probability of reporting excellent/good self-rated health. One possible explanation is the larger number of limitations and barriers faced by people with disability. In fact, according to the type of impairment, a person may face discrimination and physical, social, and attitudinal barriers, with negative consequences for individuals' perceptions of their own health.

Although living with disability or a chronic disease is associated with lower levels of self-rated health, the determinants were different for each group. On the one hand, in the case of people with chronic disease(s), individual factors such as age reduces the chances of reporting an excellent/good self-rated health. In addition, people living with chronic disease, who were insured in the subsidized regime, had lower chances of reporting excellent/good self-rated health. This may be related to their higher demand for health care services. In the contributory insurance regime, health care services are usually provided with better quality, shorter waiting times and fewer bureaucratic procedures when 
compared with services provided in the subsidized regime 45,46 . People with chronic disease(s) living in the highest socioeconomic stratum had a higher probability of reporting excellent/good seltgh. This result can be associated with the socioeconomic status of the person, since in Colombia stratum are presented information about the surroundings of the household, including public amenities (such as electricity) and infrastructure (e.g., parks). Finally, "family support" was an important determinant of reporting excellent/good self-rated health for people with chronic disease(s). Regarding people with a disability, "years of schooling", "belonging to the lowest quintile of the wealth index", "insufficient income to cover their basic needs", and "levels of family support" were the determinant of self-rated health.

In all groups (men, women, people with disability, people with chronic conditions, and people with both disability and chronic conditions), the "level of education", "not enough income to cover their needs" and "family support" were always related to self-rated health. Regarding the level of education, the probability of reporting an excellent/good health status increased. This is consistent with previous studies in which the years of education are a significant predictor of excellent/good selfrated health 47,48 . This result shows the important effect of education on an individual's health status, even in the later stages of life. Human capital accumulation across the life course positively affects the health of individuals, since individuals with higher levels of education are more likely to take better care of their health ${ }^{49}$, and, therefore, they tend to report higher levels of self-rated health.

Although our study included three different socioeconomic variables, only "income is not enough to cover their needs" was always a factor reducing the odds of excellent/good self-rated health for all groups. Individuals older than 60 years living in poor families, or families facing difficult economic situations were more likely to report bad health. Given the association between self-rated health status and morbidity and mortality, this group might have higher risks of illness and disease(s). Although this variable is not a perfect proxy of objective poverty 50 , aspects related to the perceptions of people regarding their living standards compared to their closest neighborhood or network are captured by this measure.

Family and social support is a strong predictor of excellent/good self-rated health. This result was found in all groups. In fact, reporting support provided by other family members was always positively associated with excellent/good self-rated health. Perceived social support from the family is equally important in all groups and may act as a buffer to mitigate limitations such as loneliness and emotional distress, which are common traits among older adults and especially for people with disability and/or living with chronic disease(s), who must deal with greater emotional burdens. Although it would be ideal to include a variable related to support provided by other social networks (e.g., friends, community), information about social capital was not available. Previous studies have found that receiving constant support improves individuals' levels of physical and mental health and increases their quality of life 51 ; it also reduces negative consequences of depression, can help people to cope with the negative consequences of the disease, and reduces the probability of assuming risky health behaviors such as excessive alcohol consumption or sedentarism 52 .

No significant differences were found between the levels of self-rated health of men and women. This finding contrasts with those from the literature in high-income and middle-income countries, which suggest differences between both groups 6,53; however, it is similar to the one form other studies in this topic 4,29. A more detailed analysis in this topic showed that men have higher levels of education when compared with women; thus, it can be hypothesized that men use education to compensate for lower access to health services, and that their chances of receiving information and making better judgements concerning their own health are higher. Higher levels of education among men may allow them to access health services more efficiently if poor self-rated health is perceived.

The 2030 Agenda for Sustainable Development advocates the importance of health equity and universal access to health and coverage, and specifically mentions the importance of leaving no one behind 54. Individuals older than 60 and with disabilities are among the hardest groups to reach; however, they must be targeted to achieve the Sustainable Development Goals. Thus, it is of policy and public health relevance to describe the characteristics of the older adults in the country concerned, particularly, in urban settings with large socioeconomic inequalities in which social services for older adults are scarce and public care services are limited. Our study emphasize the importance of family support, level of education, and subjective poverty as key predictors of relatively better self-rated 
health among older adults. Health services and personnel could help to enhance this factor by drawing attention to a careful consideration and a cultural acceptance of the role of caregivers of older adults. Systems that support the caregivers' role and hence increase social capital through social and economic incentives could potentially affect self-rated health evaluation.

Although our results have important policy implications, due to data limitations, it was not possible to include in the estimation model other variables related to objective health outcomes, or activities commonly associated with excellent/good self-rated health. Lifestyle variables such as smoking, exercise, diet, or sleeping habits were not available in the dataset. Therefore, it was not possible to control for those factors. Moreover, despite the inclusion of variables related to the context, no significant differences between localities were found, and it was not possible to include other control variables on this topic. Therefore, it is important that future studies to analyze if levels of self-rated health are associated with individual's area of residence, using variables such as neighborhood or district.

\section{Conclusions}

The determinants of self-rated health status of older adults in Bogotá differ between subgroups. Individuals living with disability and chronic diseases are more likely to report lower health status than people living without these conditions. Access to benefits of the contributory insurance regime and family support indicate potential routes for intervention through legislation and institutional practices among health providers to improve the self-rated health status of older adults in urban settings in Colombia and other comparable contexts.

\section{Contributors}

M. Pinilla-Roncancio contributed to the data analysis, discussion, and writing of the paper. C. González-Uribe and D. I. Lucumí contributed to the writing and discussion of results.

\section{Additional informations}

ORCID: Monica Pinilla-Roncancio (0000-00021443-4649); Catalina González-Uribe (0000-00023322-5017); Diego I. Lucumí (0000-0003-18347937).

\section{Acknowledgments}

The authors acknowledge Profamilia Colombia for providing access to the dataset.

\section{References}

1. United Nations. World population prospects: key findings and advance tables. New York: United Nations; 2017.

2. United Nations. World population aging. New York: United Nations; 2015.

3. Da Mata FA, Pereira PP, Andrade KR, Figueiredo AC, Silva MT, Pereira MG. Prevalence of frailty in Latin America and the Caribbean: a systematic review and meta-analysis. PLoS One 2016; 11:e0160019.

4. Ocampo-Chaparro JM, Zapata-Ossa HJ, Cubides-Munevar AM, Curcio CL, Villegas JD, Reyes-Ortiz CA. Prevalence of poor self-rated health and associated risk factors among older adults in Cali, Colombia. Colomb Med 2013; 44:224-31.

5. Ronconi L, Brown TT, Scheffler RM. Social capital and self-rated health in Argentina. Health Econ 2012; 21:201-8.

6. Tuesca-Molina RJ, Amed-Salazar EJ. Social capital and relationship with self-rated health. National health survey in Colombia. Colombia Med 2014; 45:7-14.

7. Reyes-Ortiz CA, Ostir GV, Pelaez M, Ottenbacher KJ. Cross-national comparison of disability in Latin American and Caribbean persons aged 75 and older. Arch Gerontol Geriatr 2006; 42:21-33. 
8. Menéndez J, Guevara A, Arcia N, León Díaz EM, Marín C, Alfonso JC. Enfermedades crónicas y limitación funcional en adultos mayores: estudio comparativo en siete ciudades de América Latina y el Caribe. Rev Panam Salud Pública 2005; 17:353-61.

9. Departamento Administrativo Nacional de Estadística. Indicadores demograficos por departamento 1985-2020. Bogotá: Departamento Administrativo Nacional de Estadística; 2018.

10. Departamento Administrativo Nacional de Estadística. Proyecciones de población 20052020 nacional, departamental y municipal por sexo, grupos quinquenales de edad. Bogotá: Departamento Administrativo Nacional de Estadística; 2018.

11. Comisión Económica para América Latina y el Caribe. El envejecimiento y las personas de edad: indicadores sociodemográficos para América Latina y el Caribe. Santiago de Chile: Comisión Económica para América Latina y el Caribe; 2009.

12. Martinez JC. Factores asociados a la mortalidad por enfermedades no transmisibles en Colombia, 2008-2012. Biomedica 2016; 36:535-49.

13. World Health Organization; The World Bank. World report on disability. Geneva: World Health Organization; 2011.

14. Departamento Administrativo Nacional de Estadística. Discapacidad: información nacional. Bogotá: Departamento Administrativo Nacional de Estadistica; 2018.

15. Ocampo-Chaparro JM. Self-rated health: importance of use in elderly adults. Colomb Med 2010; 41:275-89.

16. Lucumí DI, Gomez LF, Brownson RC, Parra DC. Social capital, socioeconomic status, and health-related quality of life among older adults in Bogotá (Colombia). J Aging Health 2015; 27:730-50.

17. Cano A, Scaturo DJ, Sprafkin RP, Lantinga LJ, Fiese BH, Brand F. Family support, self-rated health, and psychological distress. Prim Care Companion J Clin Psychiatry 2003; 5:111-7.

18. Allen J. Older people and wellbeing. London: Institute for Public Policy Research; 2008.

19. Mora PA, DiBonaventura MD, Idler E, Leventhal EA, Leventhal H. Psychological factors influencing self-assessments of health: toward an understanding of the mechanisms underlying how people rate their own health. Ann Behav Med 2008; 36:292-303.

20. Cott CA, Gignac MA, Badley EM. Determinants of self rated health for Canadians with chronic disease and disability. J Epidemiol Community Health 1999; 53:731-6.

21. Mavaddat N, Parker RA, Sanderson S, Mant J, Kinmonth AL. Relationship of self-rated health with fatal and non-fatal outcomes in cardiovascular disease: a systematic review and meta-analysis. PLoS One 2014; 9:e103509.
22. McDaid O, Hanly MJ, Richardson K, Kee F, Kenny RA, Savva GM. The effect of multiple chronic conditions on self-rated health, disability and quality of life among the older populations of Northern Ireland and the Republic of Ireland: a comparison of two nationally representative cross-sectional surveys. BMJ Open 2013; 3:e002571.

23. Wu S, Wang R, Zhao Y, Ma X, Wu M, Yan X, et al. The relationship between self-rated health and objective health status: a population-based study. BMC Public Health 2013; 13:320.

24. Murata C, Kondo T, Tamakoshi K, Yatsuya $\mathrm{H}$, Toyoshima H. Determinants of self-rated health: could health status explain the association between self-rated health and mortality? Arch Gerontol Geriatr 2006; 43:369-80.

25. Xu F, Johnston JM. Self-rated health and health service utilization: a systematic review. Int J Epidemiol 2015; 44 Suppl 1:i180.

26. Erickson W, Lee C, von Schrader S. 2012 Disability status report: United States. Ithaca: Cornell University Employment and Disability Institute; 2014.

27. Dai Y, Zhang C-Y, Zhang B-Q, Li Z, Jiang C, Huang H-L. Social support and the self-rated health of older people: a comparative study in Tainan Taiwan and Fuzhou Fujian province. Medicine (Baltimore) 2016; 95:e3881.

28. Foraker RE, Rose KM, Chang PP, McNeill AM, Suchindran CM, Selvin E, et al. Socioeconomic status and the trajectory of self-rated health. Age Ageing 2011; 40:706-11.

29. Adjei NK, Brand T, Zeeb H. Gender inequality in self-reported health among the elderly in contemporary welfare countries: a crosscountry analysis of time use activities, socioeconomic positions and family characteristics. PLoS One 2017; 12:e0184676.

30. Wong R, Peláez M, Palloni A. Self-reported general health in older adults in Latin America and the Caribbean: usefulness of the indicator. Rev Panam Salud Pública 2005; 17:323-32.

31. Asociación Probienestar de la Familia Colombiana. Encuesta Distrital de Demografía y Salud Bogotá 2011. Bogotá: Asociación Probienestar de la Familia Colombiana; 2011.

32. Pérez-Zepeda MU, Belanger E, Zunzunegui MV, Phillips S, Ylli A, Guralnik J. Assessing the validity of self-rated health with the short physical performance battery: a cross-sectional analysis of the international mobility in aging study. PLoS One 2016; 11:e0153855.

33. Lundberg O, Manderbacka K. Assessing reliability of a measure of self-rated health. Scand J Soc Med 1996; 24:218-24.

34. Altman BM, editor. International measurement of disability: purpose, method and application. The work of the Washington Group. New York: Springer; 2016. 
35. Molarius A, Janson S. Self-rated health, chronic diseases, and symptoms among middle-aged and elderly men and women. J Clin Epidemiol 2002; 55:364-70

36. Kumar S, Pradhan MR. Self-rated health status and its correlates among the elderly in India. J Public Health 2019; 27:291-9.

37. Shi L, Starfield B, Politzer R, Regan J. Primary care, self-rated health, and reductions in social disparities in health. Health Serv Res 2002; 37:529-50.

38. Departamento Nacional de Planeación. Aseguramiento. Bogotá: Departamento Nacional de Planeación; 2019.

39. Filmer D, Pritchett L. Estimating wealth effects without expenditure data- or tears: an application to educational enrolments in States of India. Demography 2001; 38:115-32.

40. Departamento Administrativo Nacional de Estadística. Estratificación en Colombia. http://www.dane.gov.co2019 (accessed on 28/ Jul/2019).

41. Vittinghoff E, Glidden DV, Shiboski SC, McCulloch CE. Regression methods in biostatistics. linear, logistic, survival, and repeated measures models. 2nd Ed. New York: Springer; 2012.

42. Parra DC, Gomez LF, Sarmiento OL, Buchner D, Brownson R, Schimd T, et al. Perceived and objective neighborhood environment attributes and health related quality of life among the elderly in Bogotá, Colombia. Soc Sci Med 2010; 70:1070-6.

43. Meireles AL, Xavier CC, Andrade ACS, Friche AAL, Proietti FA, Caiaffa WT. Self-rated health in urban adults, perceptions of the physical and social environment, and reported comorbidities: The BH Health Study. Cad Saúde Pública 2015; 31 Suppl 1:S120-35.

44. Fonta CL, Nonvignon J, Aikins M, Nwosu E, Aryeetey GC. Predictors of self-reported health among the elderly in Ghana: a cross sectional study. BMC Geriatr 2017; 17:171.

45. Garcia-Subirats I, Vargas I, Mogollón-Pérez AS, De Paepe P, Silva MRF, Unger JP, et al. Inequities in access to health care in different health systems: a study in municipalities of central Colombia and north-eastern Brazil. Int J Equity Health 2014; 13:10.
46. Garcia-Subirats I, Vargas I, Mogollón-Pérez AS, De Paepe P, Silva MRF, Unger JP, et al. Barriers in access to healthcare in countries with different health systems: a cross-sectional study in municipalities of central Colombia and north-eastern Brazil. Soc Sci Med 2014;106:204-13.

47. Borgonovi F, Pokropek A. Education and self-reported health: evidence from 23 countries on the role of years of schooling, cognitive skills and social capital. PLoS One 2016; 11:e0149716.

48. Subramanian S, Huijts T, Avendano M. Selfreported health assessments in the 2002 World Health Survey: how do they correlate with education? Bull World Health Organ 2010; 88:131-8.

49. Fletcher JM. New evidence of the effects of education on health in the US: compulsory schooling laws revisited. Soc Sci Med 2015; 127:101-7.

50. Ravallion M. Poor, or just feeling poor? on using subjective data in measuring poverty. Washington DC: World Bank; 2012. (Policy Research Working Paper, WPS 5968).

51. Wang H-H, Wu S-Z, Liu Y-Y. Association between social support and health outcomes: a meta-analysis. Kaohsiung J Med Sci 2003; 19:345-50.

52. Croezen S, Picavet HSJ, Haveman-Nies A, Verschuren WM, de Groot LC, van't Veer P. Do positive or negative experiences of social support relate to current and future health? Results from the Doetinchem Cohort Study. BMC Public Health 2012; 12:65.

53. Campos AC, Albala C, Lera L, Sanchez H, Vargas AM, Ferreira e Ferreira E. Gender differences in predictors of self-rated health among older adults in Brazil and Chile. BMC Public Health 2015; 15:365.

54. Watkins K. Leaving no one behind: an agenda for equity. Lancet 2014; 384:2248-55. 


\section{Resumen}

El objetivo fue identificar los determinantes principales de salud autoevaluada en individuos con edades comprendidas entre los 60 años o más en Bogotá, Colombia y si esos determinantes varían entre grupos. Los datos se recabaron de la Encuesta Demográfica sobre Salud de 2011 en Bogotá. Los modelos de regresión logística se estimaron para identificar los determinantes de una excelente/ buena salud autoevaluada entre personas con 60 años o mayores, viviendo en Bogotá. Asimismo, se realizó un análisis subgrupo, con el fin de identificar si los determinantes cambiaron entre grupos (hombres, mujeres, personas con discapacidad, con enfermedades crónicas, y personas viviendo con discapacidad y enfermedades crónicas. La probabilidad de informar de una excelente/buena salud autoevaluada decrece cuando la persona sufre una discapacidad, una enfermedad crónica o informa que sus ingresos no son suficientes para cubrir las necesidades básicas. En cambio, las probabilidades de informar sobre una excelente/buena salud autoevaluada se incrementan cuando la persona tiene más formación educacional e informa recibir apoyo familiar. El subgrupo de análisis revela que pese a que algunos determinantes están sólo asociados a un grupo (edad con enfermedades crónicas), en general, fueron importantes tres determinantes: años de educación, variables status socieconómico y recibir apoyo familiar. Los determinantes de salud autoevaluada para las personas mayores en Bogotá varían, dependiendo de la discapacidad y estatus de las enfermedades crónicas. Por tanto, las políticas públicas con el fin de mejorar los niveles de salud y calidad deben considerar los efectos de aquellas características sobre las percepciones individuales de su propia salud.

Personas con Discapacidad; Anciano; Enfermedad Crónica; Área Urbana

\section{Resumo}

O estudo teve como objetivos identificar os principais determinantes da autopercepção da saúde entre indivíduos com 60 anos ou mais em Bogotá, Colômbia, e averiguar se esses determinantes variam entre grupos. A fonte de dados foi a Pesquisa Nacional de Demografia e Saúde de 2011, para a cidade de Bogotá. Foram estimados modelos de regressão logística para identificar os determinantes da autopercepção da saúde excelente/boa entre pessoas com 60 anos de idade ou mais, residindo em Bogotá. Além disso, foi realizada uma análise de subgrupos com o objetivo de identificar se os determinantes mudaram entre os grupos (homens, mulheres, pessoas com deficiência, com doenças crônicas e pessoas vivendo simultaneamente com deficiência e com doenças crônicas). A probabilidade de relatar autopercepção da saúde excelente/ boa diminui quando a pessoa é portadora de deficiência ou doença crônica ou quando a renda domiciliar é insuficiente para atender as necessidades básicas. Enquanto isso, as chances de relatar autopercepção da saúde excelente/boa aumentam quando a pessoa tem maior escolaridade e recebe apoio da família. A análise de subgrupos revelou que, embora alguns determinantes só estejam associados a um grupo (idade e doenças crônicas), de maneira geral, três principais determinantes foram importantes: anos de ensino, condição socioeconômica e apoio familiar. Os determinantes da autopercepção da saúde em idosos residentes em Bogotá variam de acordo com a presença ou ausência de deficiência e doenças crônicas. Portanto, as políticas públicas que procuram melhorar os niveis de saúde e qualidade de vida devem considerar os efeitos dessas características sobre a percepção dos indivíduos em relação à própria saúde.

Pessoas com Deficiência; Idoso; Doença Crônica; Área Urbana
Submitted on 13/Mar/2019

Final version resubmitted on 13/Aug/2019

Approved on 08/Oct/2019 